\title{
THE IMPACT OF IMPROVEMENT OF WATER SUPPLY AND SANITATION FACILITIES ON DIARRHEA AND INTESTINAL PARASITES: A BRAZILIAN EXPERIENCE WITH CHILDREN IN TWO LOW-INCOME URBAN COMMUNITIES*
}

\author{
Rainer Gross** \\ Bernd Schell** \\ Maria Carmen Bisi Molina*** \\ Maria Antonia Cuelho Leão**** \\ Ulrike Strack*****
}

\begin{abstract}
GROSS, R. et al. The impact of improvement of water supply and sanitation facilities on diarrhea and intestinal parasites: a Brazilian experience with children in two low-income urban communities. Rev. Saúde públ., S. Paulo, 23: 214-20, 1989.

ABSTRACT: During the second half of 1986 the impact of the improvement of water supply and excreta disposal facilities on diarrheal diseases and intestinal parasitosis was studied in 254 children up to six years of age from two favelas (shanty towns) of Belo Horizonte, Brazil. The estimated incidence of diarrhea was 6.2 episodes/child year and the estimated period prevalence reached 31.0 episode days/ child/ year. The point prevalence of parasitosis was $70.7 \%$ (Ascaris lumbricoides: $55.4 \%$, Trichuris trichiura: $19.6 \%$, Giardia lamblia: $17.9 \%$ ). The estimated prevalence of diarrhea decreased with improvement of water supply and sanitation facilities to $45 \%$ and $44 \%$ respectively, but no statistically significant impact was observed in the case of parasitosis. School education and weaning practice were found to be other important determinants of diarrhea.
\end{abstract}

KCYYWORDS: Diarrhea, occurrence. Helminthiasis, occurrence. Water supply. Sanitation.

\section{INTRODUCTION}

In contrast to the dramatic decline in diarrheal disease morbidity and mortality rates in developed countries during the past century diarrheal diseases still represent one of the main problems in most of the developing word ${ }^{17}$. Many attempts have been made to reduce mortality and morbidity from diarrhea ${ }^{9}$. In particular, oral rehydration therapy (ORT) has been recommended by several national and international organizations as a basis for diarrhea control. ORT it is an effective and relatively inexpensive method of reducing the mortality caused by dehydration accompanying diarrhea ${ }^{16}$. However, the adaptation of ORT could also increase the dangerous belief that this can control all diarrheal diseases. Our present knowledge indicates that its effectiveness in preventing death from dysenteric or chronic diarrheas is limited?.

However, preventive, non-clinical measures for diarrhea control among young children can be justified. One of these preventive strategies is the improvement of water supply and sanitation facilities, so that transmission of the agent is prevented or at least impeded. In urban areas the improvement of water supply and sanitation facilities can be established only by the construction of high cost basic infrastructural systems. Considering the lack of capital in most developing countries, and also the lack of knowledge of the impact of water supply and excreta disposal on diarrhea, more field studies of the latter are required under different environmental and cultural conditions ${ }^{6}$.

* Supported by the Ministry of Economic Cooperation of the Federal Republic of Germany.

Deutsche Gesellschaft für Technische Zusammenarbeit-GTZ-GmbH, Section 162 - P.O. Box $5180-$ D-6236 Eschborn, Federal Republic of Germany.

*** Instituto de Nutrição do Centro de Ciências da Saúde da Universidade Federal do Rio de Janeiro -- 21941 - Rio de Janeiro, RJ - Brasil.

* * Secretaria de Saúde da Prefeitura Municipal de Belo Horizonte - Rua Tupis, 149 - 30190 - Belo Horizonte, MG Brasil.

****Deutsche Gesellschaft für Technische Zusammenarbeit - GTZ - c/o Secretaria de Estado do Trabalho e Ação Social (SETAS). Rua Gentios, 75 - 30380 - Belo Horizonte, MG - Brasil. 
In the following study, incidence, duration and prevalence of diarrhea, and the prevalence of intestinal parasites were observed in two lowincome communities of Belo Horizonte, Brazil. In both study areas a part of the population had benefited from newly introduced basic infrastructure facilities such as a water supply, excreta disposal facilities and public removal of refuse $^{18}$. Therefore it was of particular interest to study the impact of these measures on diarrheal diseases and intestinal parasite prevalence and to compare them with other socio-economic and environmental variables.

\section{MATERIAL AND METHODS}

Population studied. Belo Horizonte is the capital of the federal state of Minas Gerais, and with 2.4 million inhabitants (1986) the third largest city of Brazil. In two conglomerations of this urban area, the State Secretariat of Employment and Social Action (SETAS) and the Deutsche Gesellschaft für Technische Zusammenarbeit - gtz - are carrying out an urbanization project to improve basic infrastructure. Both communities are located in the southern center of the city $4 \mathrm{~km}$ apart from each other and subdivided into several favelas (shanty towns). In "Alto da Serra", which consists of the favelas "Vila de Nossa Senhora da Conceição", "Vila de Santana do Cafezal" "Nossa Senhora de Fátima" and "Marçola", approximately 50 thousand inhabitants live in an area of 108.0 ha. In the second conglomeration of "Barragem de Santa Lúcia" and "Vila Rita de Cássia" an area of 43.7 ha is occupied by 25 thousand inhabitants.

Eighty households of "Serra" and 60 households of "Sta. Lúcia/Vila Rita", all having at least one child below six years of age, were visited during September and October 1986. Descriptions of the communities, study populations, and surveillance methodology have been published in detail elsewhere ${ }^{3}$.

Hemoglobin. Hemoglobin concentration in the blood of the children was determined according to the hemoglobin cyanide method. The test was undertaken with the rapid test method of COMPUR Medical Technology (Equipment: COMPUR M 1000 D1; reagent: INSTANT $M$, Catalogue $N$ : 6800-501) following the instructions of the manufacturer ${ }^{3}$.

Parasitology. Detailed instructions and a receptacle for the feces of the surveyed children had been left with their mothers the day before collection. The feces were examined for parasites by the Central Laboratory of the Hospital of the Municipality of Belo Horizonte $(\mathrm{PMBH})$. The feces wer examined by the sedimentation technique as described by Goulart and Costa Leite ${ }^{10}$. All positive fecal specimens were examined once only; $31 \%$ of the examinations with a negative result were repeated, i.e., 15 cases.

Sociocultural survey. Questions on
demographic,
environmental characteristics, as well as on diet and state of health, were answered by the mothers of the children. An auxiliary worker was present during the inquiry by the nutritionist in order to establish an atmosphere of confidence between the interviewer and the mother, since the nutritionist, unlike the auxiliary, was unknown to the community. The development of the specific questions on diarrhea was based on the suggestions from the WHO Diarrheal Disease Control Programme ${ }^{20}$. The incidence data were drawn from the mother's observations of the beginning of a diarrheal episode during the previous two weeks. A diarrheal episode was defined as the occurrence of more than three liquid stools per day.

Data processing and analysis. Data were processed on the PC (Compaq II) of the "Instituto de Nutrição" of the Federal University of Rio de Janeiro. The prevalence of anaemia was defined as the percentage of the surveyed population falling below the cut-off point of $11 \mathrm{~g} / \mathrm{dl}$, as recommended by $\mathrm{WHO}^{14}$. Tests of specifically derived subhypotheses were carried out by a series of variance analyses with unequal sample size (one-factor ANOVA). This test avoids an exaggerated overestimation of smaller sample groups, which might occur in field studies. Furthermore it enables the statistical differentiation not only of continuous variables, such as age groups, but also of discontinuous variables, such as the type of water supply. Missing data accounted for less than $2 \%$ of the observations for all variables, with the exception of parasite load and hemoglobin, where $33.2 \%$ and $11.8 \%$ of observations were missing respectively.

\section{RESULTS}

Table 1 gives information about the living conditions in the two communities. The 
TABLE 1

Selected characteristics indicating socioeconomic, housing and basic infrastructure conditions in the two urban areas studied in Belo Horizonte (1986).

\begin{tabular}{|c|c|c|c|}
\hline $\begin{array}{l}\text { Socioeconomics } \\
\text { Characteristics }\end{array}$ & Serra & $\begin{array}{l}\text { Sta. Lúcia/ } \\
\text { Vila Rita }\end{array}$ & Total \\
\hline $\begin{array}{l}\text { Household members: } \\
\text { Total } \\
\text { children }<6 \text { years } \\
\text { working }\end{array}$ & $\begin{array}{l}6.1 \pm 2.7^{*} \\
2.3 \pm 0.8^{*} \\
1.9 \pm 1.1^{*}\end{array}$ & $\begin{array}{l}6.0 \pm 2.6 \\
2.2 \pm 1.0 \\
1.8 \pm 1.1\end{array}$ & $\begin{array}{l}6.1 \pm 2.7 \\
2.2 \pm 0.9 \\
1.9 \pm 1.1\end{array}$ \\
\hline $\begin{array}{l}\text { Household monthly } \\
\text { income** }\end{array}$ & $2.5 \pm 1.0$ & $2.7 \pm 1.2$ & $2.6 \pm 1.1$ \\
\hline $\begin{array}{l}\text { Duration of residence } \\
\text { (years) }\end{array}$ & $12.0 \pm 9.0 *$ & $8.5 \pm 7.3$ & $10.5 \pm 9.0$ \\
\hline $\begin{array}{l}\text { Housing conditions: } \\
\text { Brick houses }(\%)\end{array}$ & 96.3 & 88.3 & 92.9 \\
\hline No. of bedrooms & $3.2 \pm 2.0^{*}$ & $3.8 \pm 1.5$ & $3.4 \pm 1.7$ \\
\hline $\begin{array}{l}\text { piped water }(\%) \\
\text { flush toilet }(\%) \\
\text { public removal of }\end{array}$ & $\begin{array}{l}45.0 \\
26.0\end{array}$ & $\begin{array}{l}76.7 \\
23.3\end{array}$ & $\begin{array}{l}58.6 \\
25.0\end{array}$ \\
\hline $\begin{array}{l}\text { refuse (\%) } \\
\text { electrification (\%) }\end{array}$ & $\begin{array}{l}16.3 \\
92.5\end{array}$ & $\begin{array}{l}16.7 \\
98.3\end{array}$ & $\begin{array}{l}16.5 \\
95.0\end{array}$ \\
\hline
\end{tabular}

* Mean and standard deviation

** Expressed as official minimum income wage

(1986: one official minimum income wage $=57.04$ US $\$$ )

surveyed households were generally characterized by low-incomes (around 150 US\$ per month during the study period in late 1986) and often by inadequate sanitation facilities. The parents had had a modest school education and approximately $20 \%$ of them were illiterate. A little more than two-thirds of the population originated from the interior of the federal state and one-quarter were from the capital of the state itself. Compared with "Sta. Lúcia/ Vila Rita" the households of "Serra" seem to be a little more established, taking into account the proportion of brick houses. On the other hand, some of the urbanization facilities such as piped water were superior in "Sta. Lúcia/ Sta. Rita" A detailed description of the living conditions has been published elsewhere?

The children of the two communities generally showed high morbidity. At the time of the inquiry, $34.9 \%$ of the children suffered from acute respiratory infections (ARI) and $11.5 \%$ from diarrheal diseases. Episodes of diarrhea, in the total of 59, were reported in 247 children, beginning in the two weeks prior to the inquiry. Assuming little or no seasonal variation, this indicates an approximate incidence of 6.2 episodes per child per year. Since this incidence rate is based only on a short period, comparison with longitudinal data has limited value, as this is obtained during at least one year, to include seasonal rate changes. According to information from the health post personnel, a high incidence occurs during the hot summer months between December and March, whereas the incidence of diarrhea decreases during the colder winter months when, conversely, the incidence of ARI rises. As the study was carried out during the transition of seasons, one cannot expect an extremely low or high incidence rate.

According to the mothers, the mean duration of diarrheal episodes was 5.0 days, so that the estimated period prevalence amounted to 31.0 episode days per child per year or 86.9 episode days per 1,000 child observation days.

Besides diarrheal diseases, the point prevalence of parasites also showed a high rate (Table 2). Of the studied children $70.4 \%$ were infected by at least one pathogenic intestinal parasite. The main agents were helminths, followed by amoeba. However, it has to be considered that other pathogenic intestinal agents such as enterobacteria and virus were not surveyed. There was a slight difference in prevalence between the two communities. In 
"Serra" $69 \%$ were infected with parasites, whereas in "Sta. Lúcia/ Vila Rita" the rate was $73 \%$.

\section{TABLE 2}

Point prevalence of specific parasites identified in the two communities

\begin{tabular}{lcr}
\hline \multicolumn{1}{c}{ Parasites } & \multicolumn{2}{c}{ Children } \\
& $\mathrm{n}$ & $\%$ \\
\hline Children surveyed & 168 & 100.0 \\
Children with parasitosis & 119 & 70.8 \\
Parasite: & & \\
Ascaris lumbricoides & 93 & 55.4 \\
Trichuris trichiura & 33 & 19.6 \\
Giardia lamblia & 30 & 17.9 \\
Hymonolepis nano & 8 & 4.3 \\
Entamoeba histolytica & 6 & 3.6 \\
Strongyloides stercoralis & 2 & 1.2 \\
Enterobius vermicularis & 1 & 0.6 \\
\hline
\end{tabular}

Table 3 lists various potential determinants for an increased risk of diarrheal diseases and parasitosis, with special consideration of the water supply and sanitation facilities. The type of water supply statistically affected the incidence but not the duration of diarrhea, whereas the type of sanitation facilities influenced not the incidence but the duration of diarrheal diseases. The types of water supply and fecal disposal facilities did not show any statistically-significant impact on the prevalence of intestinal parasitosis.

Furthermore, some other determinants were statistically evaluated to relate them to those of sanitation. No statistically-significant differences in diarrhea morbidity between the upper and the lower income groups was observed. In contrast, education was found to be an important social determinant. The more school education both parents had had, the less was the reported incidence of diarrhea in their

TABLE 3

Statistical significance of water supply and sanitation facilities upon diarrhea and parasites compared with some selected demographic, socioeconomic and environmental variables (one - factor ANOVA; - F-values)

\begin{tabular}{|c|c|c|c|c|}
\hline Main effect & DF & Duration & Incidence & $\begin{array}{c}\text { Parasites } \\
\text { Point } \\
\text { preva- } \\
\text { lence }\end{array}$ \\
\hline Water supply & 3 & 1.40 & $7.07 * * *$ & 0.17 \\
\hline $\begin{array}{l}\text { Excreta disposal } \\
\text { facilities }\end{array}$ & 3 & $2.61 *$ & 2.25 & 0.35 \\
\hline Age of children & 5 & 0.48 & $4.17 * *$ & $4.31 * *$ \\
\hline $\begin{array}{l}\text { Sex of children } \\
\text { Number of siblings }\end{array}$ & 1 & 0.12 & 0.17 & $<0.01$ \\
\hline $\begin{array}{l}\text { under } 6 \text { years } \\
\text { Household income/ }\end{array}$ & 2 & 2.60 & 1.86 & 1.11 \\
\hline family member & 4 & 0.54 & 1.82 & 0.81 \\
\hline Instruction father & 3 & 0.52 & $3.60 *$ & 1.08 \\
\hline mother & 3 & 2.21 & $4.54 * *$ & 0.33 \\
\hline $\begin{array}{ll}\text { Origin } & \text { father } \\
& \text { mother }\end{array}$ & $\begin{array}{l}2 \\
2\end{array}$ & $\begin{array}{l}1.97 \\
3.31 *\end{array}$ & $\begin{array}{l}0.79 \\
1.10\end{array}$ & $\begin{array}{l}0.27 \\
1.78\end{array}$ \\
\hline Time of residence & 4 & $5.31 * * *$ & 1.14 & 0.56 \\
\hline Bedroom/person & 4 & 2.17 & 0.96 & 0.50 \\
\hline Electricity supply & 2 & $3.44^{*}$ & 1.12 & 0.84 \\
\hline Removal of refuse & 3 & $3.06^{*}$ & $2.73^{*}$ & 0.73 \\
\hline $\begin{array}{l}\text { Duration of breast- } \\
\text { feeding }\end{array}$ & 5 & 0.53 & $3.80^{*}$ & 0.46 \\
\hline $\begin{array}{l}\text { Time of food } \\
\text { supplementation } \\
\text { Type of first food } \\
\text { Anemia } \\
\text { Study area }\end{array}$ & $\begin{array}{l}4 \\
5 \\
1 \\
5\end{array}$ & $\begin{array}{l}0.66 \\
1.64 \\
0.24 \\
1.13\end{array}$ & $\begin{array}{l}2.57^{*} \\
2.47 * \\
0.16 \\
1.12\end{array}$ & $\begin{array}{l}1.96 \\
2.81^{*} \\
0.26 \\
2.64^{*}\end{array}$ \\
\hline
\end{tabular}

Significance level:

* $\quad \mathrm{p}<0.05$

** $\quad \mathrm{p}<0.01$

$* * *: \quad p<0.001$ 
children. The longer a family lived in their community, the lower was the duration - but not the incidence - of diarrhea. Children of mothers originating from the interior of the state showed longer diarrheal episodes than those whose mothers were from Belo Horizonte.

Type of electrical supply was also a determinant of duration. The duration of breast-feeding and the time of dietary supplementation was found to be an other determinant of diarrheal disease. Longer breast-feeding and late dietary supplementation were associated with a reduced risk of incidence. The type of weaning food was also a determinant, since the type of supplementation depended on age.

The prevalence of anemia or of parasites was not found to be associated statistically with the appearance of diarrhea. The point prevalence of parasitosis was influenced by the age of the children, since children older than one year showed higher infection rates. Further, there was a difference of prevalence between the "favelas" and significantly less parasitosis was found in one of the surveyed "favelas". Lastly, type of food was influenced on parasitosis prevalence. Children, who were fed with vegetables had a significantly higher prevalence.

Table 4 gives special attention to water supply and sanitation facilities, since those two factors are the most expensive and therefore reach the urban poor last. Households which had access to the public water supply showed a significantly lower incidence of diarrhea, whereas the duration hardly differed. However, the prevalence of diarrhea was reduced drastically $(45 \%)$ in households with piped water. Children of those households which were connected to the public sanitation system showed a lower incidence of diarrheal diseases and a shorter duration of episodes. The period prevalence for the children in households with flush toilets was $44 \%$ lower than in those without connection to the public sanitation system. But within this group the incidence and prevalence also differed quite notably, depending on the type of excreta elimination. Prevalence was highest in the group where household members deposited excreta in the backyard or in the road, leading to a prolonged episode duration in the children.

\section{DISCUSSION}

The population studied here is characterized by the high diarrhea morbidity, which in developing countries ranges between 4 to 12 episodes per child per year. The estimated annual incidence was quite similar to that of the child population of India ${ }^{2}$, Bangladesh ${ }^{4}$, The Northeast of Brazil", Guatemala ${ }^{14}$ and the recently published data from a peri-urban child population of Lima ${ }^{13}$ and much higher than in a peri-urban child population of Santiago de Chile'. Taking into consideration the point prevalence found here of 114 episode days per 1,000 child observation days, the duration of an episode averaged 6.6 days. This value approximates to that of another observation made by Kielmann et al. ${ }^{12}$

Period prevalence was only $76 \%$ of the point prevalence. This difference may be due to the fact that mothers tend to underestimate the duration of a diarrheal episode. Furthermore, it should be kept in mind that the estimated period prevalence is based only on the extrapolation of a two-week result.

\section{TABLE 4}

Estimated incidence, period prevalence (days/child/year) and duration (days) of diarrheal episodes according to water supply and sanitation facilities

\begin{tabular}{lcccc}
\hline $\begin{array}{l}\text { Sanitation } \\
\text { facilities }\end{array}$ & $\begin{array}{c}\text { Children } \\
\text { studied }\end{array}$ & Incidence & Durantion & $\begin{array}{c}\text { Period } \\
\text { prevalence }\end{array}$ \\
\hline Piped water & 139 & 5.2 & 5.0 & 26.1 \\
Waterhose from neighbor & 36 & 5.9 & 4.8 & 28.3 \\
Water tanks & 38 & 9.5 & 5.1 & 47.8 \\
Public sanitation system & 52 & 3.9 & 4.1 & 20.5 \\
No connection to public & 195 & 7.1 & 5.2 & 36.6 \\
sanitation system & 99 & 5.6 & 4.7 & 28.7 \\
Septic pit latrine & 42 & 10.8 & 4.7 & 39.7 \\
Pit latrine & 54 & 7.0 & 6.3 & 42.5 \\
Open air & & & \\
\hline
\end{tabular}


The pattern of intestinal parasites found in the feces of the children was very similar to that of children of S. Paulo's. The higher prevalence of enteroparasitosis in the children of Belo Horizonte than in those of S. Paulo was due to the different social strata surveyed in the two studies. In S. Paulo, children of all social strata were studied whereas in Belo Horizonte only "favela" children of a poor stratum were surveyed.

The lack of a statistical association between the prevalence of parasites and the appearance of diarrhea confirms that many other microorganisms such as enterobacteria and virus which were not surveyed in this study are responsible for the manifestation of diarrheas.

This study demonstrates again, that the improvement of water supplies and excreta disposal facilities may drastically reduce the prevalence of diarrhea morbidity. In different studies, a reduction has been reported of up to $82 \%$ in the case of improvements in water quality and availability and of up to $48 \%$ in the case of excreta disposal'. The decrease of morbidity observed in the communities of "Serra" and "Sta. Lúcia/ Vila Rita" of $45 \%$ and $44 \%$, respectively, can be explained only by the public sanitation system, since no other statistically significant difference in environmental or socio-economic determinants was found between the groups with or without piped water and flush toilets. This is due to the fact that connection to the public water and sanitation systems did not depend on an individual decision but on the plans of the state institution responsible for urbanization. Neither change showed any significant effect on intestinal parasitosis, which leads to the conclusion that the helminths and amoeba are transmitted mainly via food and their presence or absence is related to the state of personal hygiene.

A lack of basic personal hygiene probably caused the longer duration of diarrheal diseases. The households which deposited their excreta in a pit latrine had the highest incidence. This may be caused by insufficient isolation of the excreta so that the latrine is a permanent source of infection. The households which had a septic pit latrine demonstrated that, although they were not connected to the public sanitation system, it was possible to reduce the general prevalence of diarrhea with appropriate measures.

Besides water supply and sanitation, there existed other important determinants which indicated higher morbidity risks. Generally, income is expected to be an important social determinant for diarrhea morbidity. However, this could not be established in this study. This may have been due to the fact that in other surveys the wages of different communities were compared, whereas here, even though wage differences within the community existed, socio-cultural and school educational variables played a much more important role. The same fact was found in the surveyed communities with regard to anthropometric variables ${ }^{3}$. Therefore it has to be kept in mind that the incidence depends more on preventive measures, whereas the duration is influenced more by curative actions. It seems that those mothers who had recently moved from rural areas into the community were less informed on how to treat diarrheal diseases.

The type of electricity supply serves as a socio-cultural and socio-economic indicator for a higher risk of prolonged episodes. Because of the relatively high economic costs of the installation, only $39.3 \%$ had received an official electric connection from the public system with the installation of an electric meter.

Generally, families from the interior with lower school education, use a electricity from their neighbors.

As found in other studies ${ }^{8}$ the duration of breast-feeding and the time of dietary supplementation were associated with diarrheal diseases and parasitoses. Children up to one year of age were significantly less infected than the other age groups. Since infants are less morbile and are breast-fed for at least some of this period, the risk of infection is much lower at this age.

As the main parasites were helminths, which are mainly transferred via food, it seems that the infections resulted mainly from a lack of food hygiene in the communities.

\section{CONCLUSION}

The health situation of the surveyed children is characterized by a high prevalence of diarrheal diseases and parasitosis. The present expansion of the basic sanitation infrastructure will considerably help to reduce the incidence of diarrheal diseases.

However, emphasis must also be given to other well known options, such as promotion of exclusive breast-feeding and better weaning practices, as well as personal, domestic and food hygiene, in order to reduce the morbidity of diarrheal diseases and intestinal parasitosis in the two communities?. 
GROSS, R. et al. O impacto das medidas de melhoria do abastecimento de água e esgoto sobre a diarréia

e parasitose intestinal: experiência brasileira com crianças de comunidades de baixa renda : Rev. Saúde públ., S. Paulo, 23: 214-20, 1989.

RESUMO: Em 1986 pesquisou-se, junto a 254 crianças de ate 6 anos de idade, residentes em duas favelas de Belo Horizonte (Brasil), o impacto das medidas de melhoramento do abastecimento de água e esgoto na incidência de diarréia e parasitose intestinal. Até então, a incidência de diarréia era estimada em 6,2 casos por criança e ano, com uma duração predominante de 31,0 dias por caso/criança/ano. A taxa de difusão de parasitose alcançava 70,7\% (Ascaris lumbricoides: 55,4\%, Trichuris trichiura: 19,6\%; Giardia lamblia: $17,9 \%$ ). Após os melhoramentos no abastecimento de água e esgoto, a incidência de diarréia caiu para $45 \%$ e $44 \%$, respectivamente. Quanto à parasitose, entretanto, não se constatou nenhum impacto estatisticamente significante. Também verificou-se que o grau de educação escolar e práticas de desmame são determinantes de grande importância na incidência de diarréia.

DESCRITORES: Diarréia, incidência. Helmintíase, incidence. Abastecimento de água. Saneamento

\section{REFERENCES}

1. ARAYA, $M$. et al. Acute diarrhoeal disease in children under 7 years of age in a peri-urban slum of Santiago, Chile. J. Hyg., 95:457-67, 1985.

2. BHATNAGER, S. \& DOSAJH, U. Diarrhoeal disease morbidity in children below 5 years in urban slums of Delhi. Indian J. med. Res., 84:53-8, 1986.

3. BISI MOLINA, M.C. et al. The nutritional status of urban, low-income group children of two communities in Belo Horizonte, Brazil. Rev. Saude públ., S. Paulo, 23(2), 1989 [no prelo].

4. BLACK, R.E. et al. Longitudinal studies of infectious diseases and physical growth of children in rural Bangladesh. II - Incidence of diarrhea and association with known pathogens. Amer. J. Epidem., 115:315-24, 1982.

5. BLASER, M.J. Infectious diarrheas: acute, chronic, and latrogenic. An. intern. Med. 105:785-7, 1986.

6. ESREY, S.A. et al. Interventions for the control of diarrhoeal diseases among young children: improving water supplies and excreta disposal facilities. Bull. Wld Hlth Org., 63:757-72, 1985.

7. FEACHEM, R.G. Preventing diarrhoea: what are the policy options? Hlth Pol. Plan., 1:109-17, 1986.

8. FEACHEM, R.G. \& KOBLINSKY, M.A. Interventions for the control of diarrhoeal diseases among young children: promotion of breast-feeding. Bull. Wld Hith Org., 62:271-91, 1984.

9. FEACHEM, R.G. et al. Diarrhoeal disease control: reviews of potential interventions. Bull. Wld Hlth Org., 61:637-40, 1982.

10. GOULART, E.G. \&COSTĀ LEITE,I. Moraes parasltologia \& microbiologia humana. 2 a ed. Rio de Janeiro, Ed. Cultura Médica, 1978.

11. GUERRANT, R.L. el al. Prospective study of diarrhoeal illness in Northeastern Brazil: pattern disease, nutritional impact, etiologies and risk factors. J. infect. dis., 148:986-96, 1983.

12 . KIELMANN, A. et al. Child and maternal health services in rural India. The Narangwal experiment: integrated nutrition and health care. Baltimore, The Johns Hopkins University Press, 1983. (A World Bank Research Publication)

13. LOPEZ DE ROMAÑA, G. et al. Health and growth of infants and young children in Huáscar, Perú. Ecol. Food Nutr., 19:213-29, 1987.

14. MATA, L.J. The children of Santa Maria de la Cauque: a prospective study of health and growth. Cambridge, Mass., M.I.T. Press, 1978.

15. MONTEIRO, C.A. et al. Estudo das condiçōes de saúde das crianças do município de São Paulo 1984/85. V1l - Parasitoses intestinais. Rev. Saúde publ., S. Paulo, 22:8-15, 1988.

16. ROHDE, J.E. Selective primary health care: strategies for control of disease in the developing world. XV-Acute diarrhea. Rev. infect. Dis., 6:840-54, 1987.

17. SNYDER, J.D. \& MERSON, M.H. The magnitude of the global problem of acute diarrheal disease: a review of active surveillance data. Bull. Wld Hlth Org., 60:605-13, 1982.

18. STRACK, U. \& NASCIMENTO FILHO, M. Os $\mathrm{im}$ pactos do programa de integração urbana na $R M B H$. Belo Horizonte, Secretaria de Estado do Trabalho e Ação Social (SETAS)/ Prefeitura Municipal, 1987. (Documento IV/16-1).

19. WORLD HEALTH ORGANIZATION. Scientific Group on Nutritional Anaemias, Geneva, 1967. Report. Geneva, 1968. (Technical Report Series, 405).

20. WORLD HEALTH ORGANIZATION. Development of indicators for monitoring progress towards health for all by the year 2000. Geneva, 1981.

Received for publication: 14/10/88. Reviewed in 3/3/89. Accepted for publication: $8 / 3 / 89$. 